\title{
PENERAPAN METODE PEMBELAJARAN PEMECAHAN MASALAH UNTUK MENINGKATKAN AKTIVITAS BELAJAR DAN HASIL BELAJAR SISWA PADA MATERI PEMBELAJARAN KELISTRIKAN
}

\author{
Hasim Bisri ${ }^{1}$, Dedi Supriawan ${ }^{2}$, Tatang Permana ${ }^{3}$ \\ Departemen Pendidikan Teknik Mesin \\ Universitas Pendidikan Indonesia \\ Jl. Dr. Setiabudhi No. 207 Bandung 40154 \\ hasimbisri01@gmail.com
}

\begin{abstract}
ABSTRAK
Tujuan dari penelitian ini untuk mengetahui peningkatan aktivitas belajar dan hasil belajar siswa melalui penerapan metode pembelajaran pemecahan masalah. Metode penelitian yang digunakan adalah metode Penelitian Tindakan Kelas yang terdiri dari dua siklus. Masing-masing siklus terdiri dari dua pertemuan tatap muka mengajar yang dilakukan pada kelas XI TKR 2 SMKN 8 Bandung sebanyak 28 siswa. Metode pembelajaran pemecahan masalah adalah suatu rencana berupa pola yang didesain dengan pendekatan pemecahan masalah melalui tahap demi tahap yang dilakukan siswa selama mengikuti proses pembelajaran. Pengumpulan data yang dilakukan untuk mengukur aktivitas belajar siswa yaitu dengan menggunakan lembar observasi dan pengumpulan data untuk mengukur hasil belajar siswa yaitu dengan menggunakan test. Hasil penelitian menunjukan bahwa adanya peningkatan aktivitas belajar siswa pada siklus I dan siklus II berturutturut dalam kategori sedang dan kategori tinggi dan peningkatan hasil belajar siswa dengan n-gain ternormalisasi pada siklus I dan siklus II berturut-turut dalam kategori sedang dan kategori tinggi. Kesimpulannya bahwa dengan penerapan metode pembelajaran pemecahan masalah dapat meningkatkan aktivitas belajar dan hasil belajar siswa pada materi pembelajaran kelistrikan Kompetensi Dasar Memperbaiki Sistem Pengapian.
\end{abstract}

Kata kunci: problem solving, aktivitas belajar, hasil belajar, pengapian.

\section{PENDAHULUAN}

Pendidikan adalah salah satu sarana untuk mentransfer kebudayaan manusia dari suatu generasi ke generasi berikutnya. Kebudayaan ini akan terus berkembang secara dinamis sesuai dengan keadaan zaman dan kondisi masyarakat. Oleh karena itu, perubahan dan perkembangan kebudayaan tersebut akan mempengaruhi perkembangan pendidikan. Pentingnya peran lembaga-lembaga pendidikan sebagai salah satu media transfer kebudayaan akan terus berupaya untuk memperbaiki dan mengembangkan kualitasnya seiring dengan tuntutan perkembangan masyarakat. Begitu kompleks dan banyaknya masalah yang dialami masyarakat, menuntut lembaga-lembaga pendidikan untuk ikut andil dalam menyelesaikan berbagai permasalahan tersebut.

\footnotetext{
${ }^{1}$ Mahasiswa Departemen Pendidikan Teknik Mesin FPTK UPI

${ }^{2}$ Dosen Departemen Pendidikan Teknik Mesin FPTK UPI

${ }^{3}$ Dosen Departemen Pendidikan Teknik Mesin FPTK UPI
} 
Sementara itu, fungsi pendidikan nasional terdapat pada UU No 20 Tahun 2003 tentang Sistem Pendidikan Nasional Bab 2 Pasal 3 bahwa pendidikan nasional berfungsi mengembangkan kemampuan dan membentuk watak serta peradaban bangsa yang bermartabat dalam rangka mencerdaskan kehidupan bangsa, bertujuan untuk berkembangnya potensi peserta didik agar menjadi manusia yang beriman dan bertakwa kepada Tuhan Yang Maha Esa, berakhlak mulia, sehat, berilmu, cakap, kreatif, mandiri, dan menjadi warga negara yang demokratis serta bertanggung jawab.

Harapan untuk mencerdaskan kehidupan bangsa di atas, masih sangat jauh dari kenyataan masyarakat Indonesia. United Nations Development Programme (UNDP) merilis peringkat Humen Development Index (HDI) Indonesia di dunia yaitu berada pada peringkat 108 dari 187 negara di tahun 2013. Posisi tersebut masih menempatkan Indonesia pada kelompok menengah dan masih dibawah rata-rata dunia. Tahun 2013, nilai HDI tercatat sebesar 73,58 (skala 25 sampai 85). Sementara penduduk dengan usia sampai 24 tahun yang masih buta huruf tercatat sebesar 9,08\%. BPS mencatat angka pengangguran bertambah 300.000 orang menjadi 7,45 juta orang per Februari 2015 (BPS, 2015). Kondisi ini seiring dengan perlambatan ekonomi yang terjadi pada kuartal I-2015 hanya 4,7\%. Pengangguran paling besar terjadi pada masyarakat berpendidikan dengan lulusan Sekolah Menengah Kejuruan (SMK), yaitu sebesar 9,05\%. Dibandingkan dengan Februari 2014, juga ada kenaikan 1,84 poin.

Salah satu cara untuk mencapai tujuan pendidikan nasional, guru-guru SMK Negeri 8 Bandung diharuskan mampu memvariasikan metode-metode pembelajaran di kelas sesuai dengan perubahan dan perkembangan dunia siswanya. Metode yang hendaknya digunakan oleh guru diharapkan memiliki ciri yang sesuai dengan Permediknas No.65 Tahun 2013 tentang Standar Proses. Upaya untuk mendorong peserta didik menghasilkan karya kreatif dan kontekstual, baik individual maupun kelompok, disarankan menggunakan pendekatan pembelajaran yang menghasilkan karya berbasis pemecahan masalah. Kegiatan Belajar Mengajar (KBM) di SMK Negeri 8 Bandung masih terdapat banyaknya metode pembelajaran yang hanya mengandalkan metode ceramah dan demonstrasi saja, sehingga penggunaan metodenya kurang bervariasi. Penggunaan metode tersebut merupakan teacher centered dan akibatnya para siswa cenderung pasif dalam KBM. 
Standar Proses Pendidikan Nasional dengan apa yang terjadi di lapangan. Hal di atas juga bertentangan dengan kondisi sekarang di dalam dunia kerja yang menuntut siapapun termasuk siswa SMK untuk memecahkan masalah-masalah yang dihadapinya. Kegiatan pembelajaran di kelas pun, para siswa harus dilatih dan dibiasakan untuk memecahkan masalah melalui kompetensi yang dituntut dalam kurikulum sesuai dengan program kejuruan masing-masing.

SMK Negeri 8 Bandung yang bergerak dalam bidang teknologi, khususnya otomotif terdapat 3 (tiga) program yaitu Teknik Kendaraan Ringan (TKR), Teknik Sepeda Motor (TSM), dan Teknik Perbaikan Bodi Otomotif (TPBO). Salah satu kompetensi program TKR yang dapat meningkatkan kompetensi siswa untuk mempersiapkan dalam memasuki dunia kerja adalah materi pembelajaran kelistrikan. Untuk meningkatkan kompetensi tersebut, proses pembelajaran di kelas dan hasil belajar siswa harus memenuhi standar yang telah ditetapkan .cenderung memerlukan bantuan, salah satunya animasi untuk menangkap konsep materi yang disampaikan. Aktivitas belajar siswa pada saat KBM di salah satu materi pembelajaran kelistrikan di SMKN 8 Bandung masih terbilang belum maksimal.

Data menujukkan jumlah siswa yang tidak membaca materi pelajaran sebanyak 21 siswa $(77,7 \%)$, tidak menyimak penjelasan guru sebanyak 8 siswa $(17,9 \%)$, tidak menulis penjelasan guru sebanyak 23 siswa $(85,2 \%)$, tidak bertanya sebanyak 25 siswa $(92,6 \%)$, dan siswa yang tidak mengemukakan pendapatnya tidak ada (0\%). Kondisi tersebut masih jauh dari harapan standar proses pembelajaran dan terlihat kegiatan belajar siswa yang cenderung pasif. Masih ada siswa yang belum lulus pada materi pembelajaran kelistrikan yaitu standar kompetensi memperbaiki sistem pengapian.

Banyak faktor yang menyebabkan rendahnya aktivitas dan hasil belajar siswa. Diantara faktor tersebut bisa dijadikan identifikasi masalah diantaranya: proses pembelajaran yang cenderung teacher centere, siswa cenderung pasif dalam proses KBM, penggunaan metode pembelajaran lain tidak dilakukan, dan penggunaan metode kurang bervariatif. Perlu dicari metode pembelajaran yang lebih efektif dan efisien untuk meningkatkan aktivitas belajar dan hasil belajar siswa. Penerapan metode pembelajaran pemecahan masalah merupakan usaha untuk mengembangkan kemampuan berpikir dan bertindak dengan tepat sebagai upaya proses belajar yang lebih mendalam terhadap materi pelajaran dan semakin berperan aktifnya siswa dalam KBM. Metode pembelajaran 
pemecahan masalah mendorong proses pembelajaran yang mempusatkan pada siswa. Penerapan metode ini, peran guru tidak hanya sekedar mentransfer ilmu pengetahuan kepada para siswa saja, tetapi juga mendorong berkembangnya pemahaman siswa terhadap materi yang diajarkan, sehingga tumbuh daya nalar dan rasa keingintahuan yang dalam terhadap materi pelajaran.

Metode pembelajaran pemecahan masalah sangat menunjang untuk meningkatkan aktivitas belajar siswa. Proses pembelajarannya akan mengembangkan kemampuan berpikir siswa, lebih mengingat materi pelajaran, dan lebih berani mengambil keputusan dalam menyelesaikan masalah, sehingga lebih yakin akan pengambilan keputusan dalam bertindak. Metode pembelajaran merupakan metode yang mengandung aktivitas belajar peserta didik yang cukup tinggi, karena pada metode tersebut beberapa aktivitas mental peserta didik dapat dijangkau antara lain mengingat, membedakan, menyimpulkan, menganalisis, mensintesis, dan meramalkan (Sudjana, 2009). Metode pembelajaran pemecahan masalah tersebut merupakan salah satu jawaban. Diharapkan mampu menyelesaikan masalah masih rendahnya aktivitas belajar dan hasil belajar siswa.

\section{METODE PENELITIAN}

Penelitian ini menggunakan metode Penelitian Tindakan Kelas (PTK). PTK berguna untuk melihat aktivitas belajar dan hasil belajar siswa di setiap siklus pembelajaran. PTK mempunyai empat tahap yaitu mendesain, melaksanakan, mengobservasi, dan merefleksikan secara kolaboratif suatu pendekatan pembelajaran yang dikenal dengan satu siklus. Penelitian ini akan dilakukan dua siklus. Prosedur penelitian masing-masing siklus pembelajaran terdiri dari planning, action, observation, dan reflection.

Populasi dalam penelitian ini adalah siswa Teknik Kendaraan Ringan kelas XI SMK Negeri 8 Bandung. Pengambilan sampel dilakukan dengan teknik purposive sample dimana sampel diambil secara khusus berdasarkan tujuan dari penelitian. Sampel pada penelitian ini sebanyak 28 siswa kelas XI TKR 2 dikarenakan aktivitas dan hasil belajarnya rendah berdasarkan data sebelumnya. Instrumen yang digunakan adalah lembar observasi aktivitas guru mengajar, lembar observasi aktivitas belajar siswa, angket untuk mengetahui tanggapan siswa terhadap pelaksanaan pembelajaran, dan pre test-post test untuk mengukur 
hasil belajar. Pengujian semua instrumen penelitian ini yaitu uji validitas isi dengan cara judgment. Pengolahan data lembar aktivitas belajar siswa berupa data kuantitatif, sedangkan lembar aktivitas mengajar guru mengajar berupa data kualitatif yang dibuat kuantitatif, kemudian dideskripsikan.

Hasil observasi aktivitas belajar siswa dan aktivitas mengajar guru akan diperbandingkan di setiap siklus, sehingga bisa diketahui peningkatannya. Pengolahan data angket ditafsirkan sebagai pandangan atau tanggapan siswa saat mengalami pembelajaran dengan metode pembelajaran pemecahan masalah. Pengolahan data untuk variabel hasil belajar siswa yaitu dari hasil pre test dan post test. Hasil test diberikan skor, kemudian dinyatakan ketuntasan hasil belajarnya menggunakan Gain Ternormalisasi (N-Gain) untuk mengetahui peningkatan hasil belajar masing-masing siswa.

\section{HASIL PENELITIAN}

Hasil aktivitas mengajar guru didapat bahwa aktivitas guru di pertemuan ke-1 sebesar 25,5\%. Pertemuan ke-2 sebesar 31,9\% dan aktivitas guru mengajar mengalami peningkatan. Idealnya aktivitas guru yang dilakukan sebesar 100\% (47 kegiatan) sesuai dengan yang rencanakan pada RPP. Aktivitas guru mengajar dengan metode pembelajaran pemecahan masalah rata-rata sebesar $28,7 \%$.

Hasil angket siklus I didapat rata-rata tanggapan siswa terhadap jalannya pembelajaran dengan metode pemecahan masalah dinilai positif. Hal ini menandakan bahwa guru tergolong berhasil melaksanakan metode pembelajaran problem solving. Hasil observasi aktivitas belajar siswa yaitu rata-rata aktivitas belajar siswa mengalami peningkatan dan berkategori sedang, sebesar 0,67.

Hasil penelitian siklus I menunjukkan pembelajaran pada KD memperbaiki sistem pengapian dengan menggunakan metode pembelajaran pemecahan masalah masih kurang maksimal. Masih terdapat kekurangan dan perlu adanya perbaikan pada siklus II. Berdasarkan refleksi dengan guru mata pelajaran dan data-data yang terkumpul pada pembelajaran siklus I, kekurangan-kekurangannya antara lain: aktivitas siswa sebagian besar masih belum optimal, hasil belajar siswa yang memenuhi dibawah $75, \%$, pengaturan kondisi tempat duduk siswa belum kondusif, diskusi belum terarahkan dengan baik, dan siswa masih menggunakan satu modul untuk dua siswa. 
Pada siklus II, aktivitas belajar siswa masih kurang maksimal terutama pada beberapa item amatan dan hasil belajar siswa masih kurang. Jumlah siswa yang memenuhi KKM-nya masih kurang dari 71,4\%. Hasil aktivitas mengajar guru didapat bahwa aktivitas guru di pertemuan ke-3 sebesar 59,6\%. Sementara itu di pertemuan ke-4 sebesar 68,1\%, sehingga akativitas guru mengalami peningkatan. Idealnya aktivitas guru yang dilakukan sebesar 100\% (47 kegiatan) sesuai dengan yang direncakan pada RPP. Aktivitas guru dengan penerapan metode pembelajaran pemecahan masalah rata-rata selama pembelajaran sebesar $63,8 \%$. Data hasil angket siklus I didapat rata-rata tanggapan siswa terhadap jalannya pembelajaran pada siklus II ke arah positif dan cenderung mengarah ke arah yang lebih baik daripada tanggapan di pembelajaran siklus I.

Data hasil observasi aktivitas siswa yaitu rata-rata aktivitas belajar siswa dari pertemuan ke-3 ke pertemuan ke-4 mengalami peningkatan. Aktivitas belajar siswa pada siklus II termasuk pada kategori tinggi. Hasil belajar siswa pada siklus II dengan N-Gain sebesar 0,78 termasuk pada kategori tinggi.

\section{PEMBAHASAN}

Aktivitas guru mengajar perlu dilihat, diukur, dan dinilai. Hal tersebut harus dilakukan karena bagaimanapun keberhasilan aktivitas belajar dan hasil belajar siswa sangat dipengaruhi oleh keterampilan guru mengajar. Keterampilan mengajar dalam hal ini adalah tindakan seorang guru dalam menerapkan metode pembelajaran pemecahan masalah. Proses belajar siswa akan berpengaruh juga terhadap hasil belajar siswa. Belajar adalah sebagai pengalaman sendiri dalam interaksi dengan lingkungannya (Slameto, 2003). Interaksi dengan lingkungan inilah, peran guru untuk menciptakan siswa berinteraksi dengan lingkungannya dalam bentuk penerapan metode pembelajaran yang dipakai. Oleh karena itu, metode yang dipakai hendaknya mengandung banyak aktivitas belajar. Hal tersebut bertujuan agar setiap siswa melakukan proses belajar.

Metode pembelajaran pemecahan masalah merupakan metode yang mengandung aktivitas belajar peserta didik yang cukup tinggi, karena pada metode tersebut beberapa aktivitas mental peserta didik dapat dijangkau (Sudjana, 2009). Oleh karena itu, berdasarkan pemaparan di atas aktivitas guru harus dilihat, diukur, dan dinilai. Aktivitas guru pada penelitian ini dilihat berdasarkan penerapan metode pembelajaran pemecahan 
masalah. Tahap-tahap pada penerapan metode pemecahan masalah adalah tahap orientasi, tahap identifikasi masalah, tahap mencari alternatif pemecahan masalah, tahap menilai alternatif pemecahan masalah, dan tahap menarik kesimpulan.

Hasil observasi aktivitas guru dari siklus I ke siklus II, aktivitas guru mengajar mengalami peningkatan. Rata-rata aktivitas guru mengajar di siklus I adalah 28,7\%, sedangkan rata-rata aktivitas guru mengajar di siklus II adalah 63,8\%. Penerapan metode pembelajaran pemecahan masalah yang dilakukan oleh guru semakin membaik. Aktivitas guru pada siklus I masih sangat jauh dari harapan yaitu hanya 28,7\%. Hal ini karena guru belum terbiasa dengan menggunakan metode pembelajaran pemecahan masalah. Sementara itu, aktivitas guru mengajar pada siklus II, semakin membaik yaitu 63,8\%. Hal ini memperlihatkan bahwa kegiatan refleksi dari siklus I berperan penting untuk perbaikan aktivitas guru pada siklus ke-2. Semakin baiknya aktivitas guru mengajar dengan metode pemecahan masalah berpengaruh terhadap semakin baiknya aktivitas belajar siswa.

Tanggapan siswa melalui angket terhadap pelaksanaan metode pembelajaran pemecahan masalah terjadi ke arah positif. Lebih dari setengah dari jumlah siswa menanggapi positif saat mengikuti penerapan metode pembelajaran pemecahan masalah. Tanggapan siswa terhadap pelaksanaan pembelajaran siklus II adalah kearah positif dan lebih baik dari siklus I. Lebih dari setengah dari jumlah siswa menanggapi positif saat mengikuti penerapan metode pembelajaran pemecahan masalah dan jumlah siswa yang menanggapi positif lebih banyak daripada di pembelajaran siklus I. Penerapan metode pembelajaran pemecahan masalah semakin membaik, sehingga dapat disimpulkan bahwa guru dipastikan menerapkan metode tersebut dengan tujuan untuk meningkatkan aktivitas belajar dan hasil belajar siswa.

Kaitan antara guru mengajar, aktivitas belajar siswa, dan hasil belajar siswa. Aktivitas belajar siswa adalah keterlibatan siswa dalam bentuk sikap, pikiran, perhatian dalam kegiatan belajar guna menunjang keberhasilan proses belajar mengajar dan memperoleh manfaat dari kegiatan tersebut. Keterlibatan siswa dalam aktivitas belajar akan menunjang keberhasilan proses belajar. Walaupun ada kemungkinan siswa yang melakukan aktivitas belajar belum tentu melakukan proses belajarnya. Proses belajar bermakna berarti informasi baru diasimilasikan dalam struktur pengertian lamanya. Belajar menghafal hanya perlu bila siswa mendapatkan fenomena atau informasi yang sama sekali baru dan belum 
ada hubungannya dalam struktur pengertian lamanya. Pengetahuan siswa selalu diperbarui dan dikontruksikan terus menerus. Jelaslah bahwa teori belajar bermakna bersifat konstruktif karena menekankan proses asimilasi dan akomodasi fenomena, pengalaman, dan fakta baru kedalam konsep atau pengertian yang sudah dimiliki siswa sebelumnya.

Namun demikian, hal itu ada faktor-faktor lain ketika siswa melakukan aktivitas belajar, akan tetapi dia tidak melakukan proses belajar, diantaranya; motivasi kurang, kurang konsentrasi, kecerdasan, minat, bakat, dan lain sebagainya. Aktivitas belajar siswa pada penelitian ini dilihat berdasarkan hasil observasi. Kegiatan observasi dilakukan oleh seorang observer dengan mengisi lembar observasi untuk melihat aktivitas belajar setiap siswa.

Hasil aktivitas belajar siswa di pertemuan ke-1 sebesar 54,4\%, dan pertemuan ke-2 sebesar 62,5\%. Sehingga rata-rata aktivitas belajar siswa di siklus I adalah 58,5\%. Rata-rata aktivitas belajar tersebut termasuk dalam kategori sedang. Hasil aktivitas belajar siswa yang terkategori masih sedang tersebut juga bisa dipengaruhi oleh keberhasilan aktivitas guru dengan penerapan metode pemecahan masalah. Aktivitas guru pada siklus I tersebut hanya sebesar $28,7 \%$. Sementara itu, berdasarkan data yang didapat siklus II, aktivitas belajar siswa di pertemuan ke-3 sebesar 68\%, dan di pertemuan ke-4 sebesar $73 \%$. Sehingga rata-rata aktivitas belajar siswa di siklus II adalah 70,5\%. Rata-rata aktivitas belajar tersebut termasuk dalam kategori tinggi. Aktivitas belajar siklus II tersebut juga dipengaruhi oleh aktivitas yang dilakukan oleh guru pada siklus II. Aktivitas guru pada siklus II tersebut sebesar 63,8\%. Oleh karena itu, semakin baik penerapan metode pemecahan masalah, semakin baik pula aktivitas belajar siswa.

Secara empiris bahwa penerapan metode pembelajaran pemecahan masalah dapat meningkatkan aktivitas belajar siswa. Metode pemecahan masalah dapat meningkatkan aktivitas pembelajaran siswa (Sanjaya, 2006). Semakin baik penerapan suatu metode pembelajaran pemecahan masalah, semakin baik pula hasil aktivitas belajar siswa. Namun demikian, dalam penerapannya harus disesuaikan dengan karakteristik siswa, tujuan pembelajaran, sarana dan prasarana yang tersedia, dan lain sebagainya. Semakin baik aktivitas belajar siswa, akan berpengaruh juga terhadap hasil belajarnya.

Metode pemecahan masalah merupakan teknik yang bagus untuk memahami isi pelajaran. Ketika siswa memahami isi pelajaran, maka akan semakin baik terhadap hasil 
belajarnya, sehingga tujuan belajar di kelas pun tercapai dengan baik. Hasil belajar siswa pada penelitian ini diukur dengan menggunakan post test. Sebelum siswa melaksanakan post test, mereka melaksankan pre test terlebih dahulu, guna untuk mengetahui kemampuan awal siswa (aspek kognitif) dan juga mengetahui peningkatan hasil belajarnya. Berdasarkan data empiris, dihasilkan peningkatan hasil belajar pada siklus I ( $N$-Gain) sebesar 0,67 (dalam kategori sedang), sedangkan peningkatan hasil belajar pada siklus II (N-Gain) sebesar 0,78 (tinggi). Berdasarkan data hasil belajar siswa siklus I ke siklus II, terbukti secara empiris bahwa penerapan metode pembelajaran pemecahan masalah dapat meningkatkan hasil belajar siswa.

Aktivitas mengajar guru dalam menerapkan metode pembelajaran, aktivitas belajar, dan hasil belajar siswa sudah menuju kea rah yang baik. Kegiatan pembelajaran, hakekatnya antara guru, siswa, dan interaksi antara guru dan siswa sangat menunjang terhadap ketercapaian suatu tujuan belajar. Guru sebagai pelaku the leader di kelas, harus mampu menciptakan dan mengelola suasana belajar yang banyak menstimulus. Guru harus mengkondisikan siswa untuk banyak melakukan aktivitas belajar melalui penerapan suatu metode pembelajaran. Siswa dengan berbagai latar belakang dan situasi emosional masingmasing ketika di kelas harus dikondisikan agar mereka benar-benar mengalami yang namanya proses belajar melalui berbagai jenis aktivitas belajar. Pada akhirnya untuk mencapai tujuan belajar yang telah direncanakan sebelumnya. Mengajar efektif yaitu kemahiran (guru) dalam menyajikan bahan pelajaran dengan meramu (berbagai) penggunaan metode mengajar (Suhardan, 2010). Strategi dan metode pembelajaran hendaknya mempertimbangkan prinsip-prinsip: orientasi pada tujuan, aktivitas belajar, individualisasi, dan integritas (keseluruhan pribadi siswa). Oleh karena itu, hasil penelitian ini bisa menjadi pertimbangan bagi guru saat memutuskan untuk menerapkan suatu metode pembelajaran secara efektif di kelas demi tercapainya tujuan pembelajaran.

\section{KESIMPULAN}

Penelitian ini disimpulkan, sebagai berikut: ada peningkatan aktivitas belajar siswa yang positif melalui penerapan metode pembelajaran pemecahan masalah pada kegiatan pembelajaran kelistrikan KD memperbaiki sistem pengapian. Peningkatan hasil belajar 
siswa dari sedang menjadi tinggi melalui penerapan metode pembelajaran pemecahan masalah pada kegiatan pembelajaran kelistrikan KD memperbaiki sistem pengapian.

\section{DAFTAR PUSTAKA}

BPS. (2015). Angka Harapan Hidup Penduduk Beberapa Negara (tahun), 1995-2015. [Online]: Tersedia http://www.bps.go.id/linktabelstatis/view/id/1517 (24 Juni 2015).

Sanjaya, W. (2006). Strategi Pembelajaran Berorientasi Standar Proses Pendidikan. Jakarta: Kencana Persada Media.

Slameto. (2003). Belajar dan Faktor-faktor yang mempengaruhinya. Jakarta: Rineka Cipta.

Supardan, D. (2010). Supervisi Profesional. Bandung: Alfa Beta.

Sudjana, N. (2009). Dasar-Dasar Proses Belajar. Bandung: Sinar Baru Algensindo. 